\title{
Udział partnerów społecznych w tworzeniu ustawowego prawa pracy
}

Przedmiotem poniższej analizy jest zagadnienie, na które zazwyczaj $\int$ nie zwraca się uwagi podczas prac nad kolejnymi nowelizacjami ustawowego prawa pracy, a które ma niewątpliwe znaczenie dla efektywnego stosowania tego prawa oraz dla jego rozwoju. Chodzi mianowicie o sposób tworzenia projektów ustawowych aktów prawnych z zakresu prawa pracy czy ujmując szerzej - z zakresu prawa socjalnego. Jak się wydaje, w literaturze przedmiotu niekwestionowany jest pogląd, iż naczelną zasadą organizacji procesu prawotwórczego w dziedzinie prawa pracy winna być partycypacja w tym procesie partnerów społecznych, czyli przedstawicieli pracowników i pracodawców ${ }^{1}$. Mówiąc inaczej, chodzi o to, by związkom zawodowym i organizacjom pracodawców zapewnić udział w pracach nad założeniami nowych aktów prawnych, jak i w fazie opracowywania szczegółowych rozwiązań legislacyjnych.

Postawić można w związku z tym pytanie, jaki jest obecnie udział partnerów społecznych $\mathrm{w}$ tworzeniu prawa pracy (lub szerzej - prawa socjalnego), a następnie - czy taki ich udział uznać należy w dalszej perspektywie za wystarczający.

1. Zasady udziału partnerów społecznych w tworzeniu prawa pracy na gruncie obecnego stanu prawnego, w szczególności według ustawy o związkach zawodowych oraz według ustawy o Komisji Trójstronnej ds. Społeczno-Gospodarczych

W myśl art. 19 ustawy z 23 maja 1991 r. o związkach zawodowych (t.j. DzU z 2014, poz. 167) reprezentatywna organizacja związkowa w rozumieniu ustawy z dnia 6 lipca 2001 r. o Trójstronnej Komisji do Spraw

* Dr hab. prof. nadzw., Katedra Prawa Ubezpieczeń Społecznych i Polityki Społecznej oraz Katedra Prawa Pracy/Zakład Prawa Rynku Pracy, Wydział Prawa i Administracji Uniwersytetu Łódzkiego.

1 T. Zieliński, Reforma prawa pracy (Problemy legislacyjne), „Państwo i Prawo” 2002, nr 5, s. 29-30. 
Społeczno-Gospodarczych i wojewódzkich komisjach dialogu społeczne$\mathrm{go}^{2}$ ma prawo opiniowania założeń i projektów aktów prawnych $\mathrm{w}$ zakresie objętym zadaniami związków zawodowych (z wyjątkiem projektu budżetu państwa oraz projektu ustawy budżetowej - o których dalej). Stosownie do przepisów ustawy o Trójstronnej Komisji status takich reprezentatywnych organizacji przysługuje obecnie Niezależnemu Samorządnemu Związkowi Zawodowemu "Solidarność", Ogólnopolskiemu Porozumieniu Związków Zawodowych oraz Forum Związków Zawodowych. Organy władzy i administracji państwowej, a także organy samorządu terytorialnego kierują założenia albo projekty aktów prawnych do odpowiednich władz statutowych wymienionych organizacji związkowych, określając termin przedstawienia opinii, nie krótszy niż 30 dni (ze względu na ważny interes publiczny termin ten może zostać skrócony do 21 dni). Nieprzedstawienie opinii we wskazanym terminie uważa się za rezygnację $z$ prawa jej wyrażenia. $W$ razie zaś odrzucenia $\mathrm{w}$ całości lub w części stanowiska związku, właściwy organ informuje o tym związek na piśmie, podając uzasadnienie swojego stanowiska. Konsekwencją takiej rozbieżności stanowisk jest uprawnienie związku zawodowego do przedstawienia swojej opinii na posiedzeniu właściwej komisji sejmowej, senackiej lub samorządu terytorialnego.

Analogiczne uprawnienie na podstawie art. 16 ustawy z 23 maja 1991 r. o organizacjach pracodawców (DzU, 1991, nr 55, poz. 235 ze zm.) mają reprezentatywne w rozumieniu ustawy o Trójstronnej Komisji organizacje pracodawców. W obecnej chwili status taki posiadają: Konfederacja Pracodawców Polskich, Polska Konfederacja Pracodawców Prywatnych, Związek Rzemiosła Polskiego oraz Business Centre Club - Związek Pracodawców. Wskazany przepis gwarantuje tym organizacjom wykonywanie przedmiotowych uprawnień na równi ze związkami zawodowymi - tryb opiniowania określony jest także $w$ tym przypadku przez odpowiednio stosowany art. 19 ustawy o związkach zawodowych.

Inne zasady przyjęte zostały do opracowania założeń projektu budżetu państwa oraz projektu ustawy budżetowej. W tym przypadku w myśl art. 3 ustawy o Trójstronnej Komisji procedurę tworzą trzy etapy konsultacji, dotyczące kolejno:

1) wstępnej prognozy wielkości makroekonomicznych stanowiących podstawę do prac nad projektem ustawy budżetowej na rok następny oraz propozycji dotyczących wzrostu w następnym roku wynagrodzeń w gospodarce narodowej i emerytur i rent z Funduszu Ubezpieczeń Społecznych,

${ }^{2}$ Ustawa z dnia 6 lipca 2001 r. o Trójstronnej Komisji do Spraw Społeczno-Gospodarczych i wojewódzkich komisjach dialogu społecznego (DzU, 2001, nr 100, poz. 1080, ze zm.); cyt. dalej jako ustawa o Trójstronnej Komisji. 
2) założeń projektu budżetu państwa na rok następny, oraz

3) projektu ustawy budżetowej na rok następny.

Zgodnie z przepisami ustawy o Trójstronnej Komisji strona rządowa w Komisji przedstawia wymienione wyżej dokumenty $\mathrm{w}$ określonych w ustawie terminach (odpowiednio: do dnia 10 maja każdego roku; do dnia 15 czerwca każdego roku; oraz nie później niż 20 dni przed przedstawieniem projektu ustawy budżetowej Sejmowi). Strony pracowników i pracodawców w przewidzianych terminach (odpowiednio: do dnia 20 maja każdego roku; do dnia 20 lipca każdego roku; nie później niż w szóstym dniu roboczym po dniu, w którym otrzymały projekt ustawy budżetowej) zajmują wspólne stanowisko w sprawie każdej z propozycji. W przypadku, gdy w powyższych terminach strony nie uzgodnią wspólnego stanowiska, każda ze nich (pracownicza i pracodawcza) może zająć odrębne stanowisko w sprawie tych propozycji - w tym celu ustawodawca przewiduje kolejne stosowne terminy (odpowiednio: do 25 maja, do 25 lipca oraz $\mathrm{w}$ ciągu następnych trzech dni roboczych). Jeżeli jednak w ostatnio wskazanych terminach strona pracownicza albo pracodawcza (tj. organizacje związkowe tworzące stronę pracowniczą oraz organizacje pracodawców tworzące stronę pracodawczą) nie uzgodni stanowiska w sprawie tych propozycji, opinię $\mathrm{w}$ tej kwestii może przedstawić każda $\mathrm{z}$ organizacji, której przedstawiciele reprezentują stronę w Komisji - w kolejnych wyznaczonych terminach (odpowiednio: do dnia 30 maja; do dnia 31 lipca; w ciągu następnych dwu dni roboczych). Nieprzedstawienie opinii w wyznaczonych terminach oznacza rezygnację z prawa do jej wyrażenia.

W tym miejscu wskazać należy jeszcze uprawnienie przewidziane w art. 7 ustawy z 23 grudnia 1999 r. o kształtowaniu wynagrodzeń w państwowej sferze budżetowej oraz o zmianie niektórych ustaw (DzU z 2011 r., nr 79, poz. 431 ze zm.). Jest to procedura uzgadniania w ramach Trójstronnej Komisji średniorocznych wskaźników wzrostu wynagrodzeń dla pracowników sfery budżetowej nieobjętych mnożnikowymi systemami wynagrodzeń. W tym przypadku Rada Ministrów do dnia 15 czerwca przedkłada Trójstronnej Komisji oraz ogólnokrajowym organizacjom związków zawodowych zrzeszającym pracowników państwowej sfery budżetowej, propozycję średniorocznych wskaźników wzrostu wynagrodzeń $\mathrm{w}$ państwowej sferze budżetowej na rok następny wraz ze wskazanymi w ustawie informacjami dodatkowymi. Organizacje związkowe w terminie 20 dni od dnia przedłożenia tej propozycji winny przedstawić opinię $\mathrm{w}$ tej kwestii - brak opinii uważany jest za rezygnację z prawa jej wyrażenia. W ramach natomiast Komisji Trójstronnej strony - rządowa, pracownicza i pracodawcza - uzgadniają owe wskaźniki w drodze uchwały - jeśli tak się stanie, Rada Ministrów jest zobowiązana uwzględnić w projekcie ustawy budżetowej poziom wynagrodzeń, który 
zagwarantuje osiągnięcie przez wskaźniki uzgodnionej wysokości. Jeżeli jednak w terminie do dnia 20 lipca nie nastąpi uzgodnienie wspólnego stanowiska, Rada Ministrów sama decyduje o wysokości wskaźników.

Uprawnienia reprezentatywnych w rozumieniu ustawy o Trójstronnej Komisji związków zawodowych i organizacji pracodawców w zakresie tworzenia prawa rozciągają się też na porządek prawny Unii Europejskiej. Jest to wynikające $\mathrm{z}$ art. $19^{1}$ ustawy o związkach zawodowych oraz art. $16^{1}$ ustawy o organizacjach pracodawców prawo do opiniowania dokumentów konsultacyjnych Unii Europejskiej, a w szczególności białych ksiąg, zielonych ksiąg i komunikatów oraz projektów aktów prawnych Unii Europejskiej, w zakresie objętym zadaniami związków zawodowych i organizacji pracodawców. Opiniowanie dotyczy w szczególności projektów rozporządzeń, dyrektyw oraz decyzji, które według art. 289 Traktatu o Funkcjonowaniu Unii Europejskiej (DzU z 2004 r., nr 90, poz. 864/2, ze zm.) są aktami ustawodawczymi przyjmowanymi w zwykłej albo specjalnej procedurze ustawodawczej. Ustawodawca polski nie określił terminu, w jakim konsultacja winna się odbyć, pozostawiając decyzję uprawnionemu organowi władzy lub administracji państwowej, który powinien mieć na uwadze, że termin przekazania opinii do organu Unii nie może co do zasady przekroczyć ośmiu tygodni (art. 4 Protokołu w sprawie roli parlamentów narodowych w Unii Europejskiej, stanowiącego część Traktatu o Funkcjonowaniu Unii Europejskiej) $)^{3}$.

Innym uprawnieniem przysługującym reprezentatywnym $\mathrm{w}$ rozumieniu ustawy o Trójstronnej Komisji organizacjom związków zawodowych i organizacjom pracodawców jest przewidziane w art. 20 ustawy o związkach zawodowych oraz $\mathrm{w}$ art. $16^{2}$ ustawy o organizacjach pracodawców prawo występowania z wnioskami o wydanie lub zmianę ustawy albo innego aktu prawnego $\mathrm{w}$ zakresie spraw objętych zadaniami związku zawodowego bądź organizacji pracodawców. Wnioski dotyczące ustaw kierowane są do posłów lub organów mających prawo inicjatywy ustawodawczej. To ostatnie ustalenie świadczy, że analizowane uprawnienie partnerów społecznych nie jest równoznaczne z przyznaniem im prawa inicjatywy ustawodawczej, co pozwoliłoby przedstawiać własne rozwiązania na forum parlamentu. W przypadku aktów prawnych niższego rzędu wnioski kieruje się do organów uprawnionych do ich wydania. Organ państwowy, do którego został skierowany wniosek, obowiązany jest $\mathrm{w}$ terminie 30 dni przedstawić związkowi zawodowemu swoje stanowisko, a w razie, gdy jest ono negatywne - także jego uzasadnienie.

Przytoczone powyżej procedury przygotowania projektów aktów prawnych dowodza, że w warunkach polskich organy władzy państwo-

${ }^{3}$ Por. M. Włodarczyk, w: System prawa pracy, t. V, Zbiorowe prawo pracy, red. K.W. Baran, Warszawa 2014, s. 416-417. 
wej zdominowały ten proces także w sferze prawa istotnie oddziałującego na sytuację podmiotów rynku pracy, tj. przedsiębiorców i osób zatrudnionych. Udział w tym procesie partnerów społecznych ma bowiem charakter wyłącznie opiniodawczy. Konsultacje, w których mogą uczestniczyć przedstawiciele związków zawodowych oraz organizacji pracodawców, nie są wiążące ${ }^{4}$. Co więcej - uzgodnione w trakcie procedury konsultacyjnej z partnerami społecznymi wersje aktu prawnego mogą zawsze zostać radykalnie zmienione $\mathrm{w}$ trakcie dalszej procedury legislacyjnej.

\section{Tworzenie prawa pracy przez Międzynarodową Organizację Pra-} cy oraz udział przedstawicieli pracowników i pracodawców w tworzeniu projektów aktów prawa wtórnego w Unii Europejskiej

W praktyce międzynarodowej spotykamy rozwiązania, które pozwalają partnerom społecznym w sposób bardziej stanowczy forsować własne koncepcje dotyczące treści regulacji z zakresu prawa socjalnego. Klasycznym przykładem jest tu procedura tworzenia norm na forum Międzynarodowej Organizacji Pracy, gdzie przedstawiciele pracodawców i pracowników dysponuja, na równi z przedstawicielami rządów państw członkowskich, głosem stanowczym podczas przyjmowania projektów aktów prawnych. Nie cierpi na tym poziom stanowionego prawa. Standard regulacji tworzonych przez MOP uwzględnia w należytym stopniu interesy wszystkich zainteresowanych podmiotów: przedsiębiorców, pracowników oraz państwa. Zarazem MOP stosunkowo szybko stara się w różnej prawnej formie reagować na istotne problemy rynku pracy, a poprzez to także na związane $\mathrm{z}$ zatrudnianiem problemy przedsiębiorców. Należy zdać sobie jednak sprawę, że model przyjęty przez MOP wynika ze specyfiki działania tej organizacji i trudny byłby do stosowania w przypadku krajów członkowskich. Z drugiej strony ważne jest, że pokazuje zalety udziału przedstawicieli pracowników i pracodawców w tworzeniu standardów prawnych.

Tak poważny udział partnerów społecznych w tworzeniu prawa pracy nie jest jednak wyłącznie cechą działania MOP. Wiele bowiem do powiedzenia mają oni także w ramach struktur Unii Europejskiej, gdzie można zauważyć daleko idące ich upodmiotowienie w sferze tworzenia prawa socjalnego. Już w roku 1974 Komisja Europejska za jeden z ważnych czynników oddziałujących na rozwój prawa socjalnego we Wspólnotach uznała umożliwienie związkom zawodowym i organizacjom pracodawców

${ }^{4}$ Wyjątkiem jest uzgodnienie średniorocznych wskaźników wzrostu wynagrodzeń dla pracowników sfery budżetowej przez strony Trójstronnej Komisji w drodze uchwały, która będzie wiązać Radę Ministrów. Z tym jednak, że uchwała nie dojdzie do skutku bez poparcia strony rządowej - a co za tym idzie, strona ta zawsze może zablokować jej przyjęcie, jeśli jej treść kolidowałaby z zamierzeniami Rady Ministrów. 
uczestniczenia w decydowaniu o sprawach ekonomicznych i społecznych przez organy wspólnotowe ${ }^{5}$. Przełomowe w tym zakresie znaczenie miało przyjęte $\mathrm{w}$ ramach Traktatu z Maastricht (1992) porozumienie dotyczące polityki socjalnej, które w interesującym nas zakresie określiło pozycję związków zawodowych i organizacji pracodawców poprzez to, że:

- po pierwsze, na Komisję nałożono obowiązek konsultowania z partnerami społecznymi kierunków działań oraz treści projektowanych aktów prawnych,

- po drugie - dopuszczono możliwość zawierania na szczeblu wspólnotowym układów zbiorowych pracy, dla których przewidziano dwojaki tryb wprowadzania w życie: albo przez odwołanie się do procedur układowych obowiązujących w danym kraju, albo przez decyzję Rady podjętą na wspólną prośbę stron układu - poprzez to związki zawodowe i organizacje pracodawców zyskały możliwość kształtowania wspólnotowego prawa pracy 6 .

Obecnie procedurę tę określają przepisy art. 154 i 155 Traktatu o funkcjonowaniu Unii Europejskiej (TFUE). Otóż Komisja jest zobowiązana popierać konsultacje pomiędzy partnerami społecznymi na poziomie Unii i podejmować wszelkie właściwe środki w celu ułatwienia im dialogu, zapewniając stronom zrównoważone wsparcie. Status owych partnerów 486 po stronie pracodawczej mają Konfederacja Europejskiego Biznesu (BUSINESSEUROPE), Europejskie Stowarzyszenie Rzemiosła oraz Małych i Średnich Przedsiębiorstw (UEAPME), a także Europejskie Centrum Pracodawców i Przedsiębiorstw Publicznych (CEEP); ze strony zaś pracowników jest to Europejska Konfederacja Związków Zawodowych (ETUC). Celem tych konsultacji jest w pierwszej kolejności ustalenie możliwego kierunku przyszłych działań w zakresie polityki społecznej. Jeśli po konsultacjach podjęcie takich działań zostanie uznane przez Komisję za pożądane, konsultuje się z partnerami społecznymi treść konkretnego przedsięwzięcia (wniosku). Co więcej, na tym etapie podkreślić należy wynikający z regulacji art. 154 ust. 4 TFUE przywilej pierwszeństwa dla tworzenia prawa socjalnego w drodze dialogu społecznego przez partnerów społecznych - na ich wspólny wniosek Komisja jest bowiem obowiązana umożliwić im w okresie do dziewięciu miesięcy uregulowanie danej sprawy w drodze porozumienia społecznego zawartego na szczeblu europejskim. Wreszcie, zgodnie z art. 155 TFUE, partnerzy społeczni mogą wystąpić do Komisji z wnioskiem, by wynegocjowane przez nich porozumienie społeczne zostało wykonane w drodze decyzji Rady na wniosek Komisji. W takim

${ }^{5}$ L. Mitrus, Tendencje rozwojowe wspólnotowego prawa pracy, „Państwo i Prawo” 2003, nr 7, s. 35 .

${ }^{6}$ Ibidem, s. 40-41; A.M. Świątkowski, Europejskie prawo socjalne, t. I, Specyfika, stanowienie i stosowanie europejskiego prawa socjalnego, Warszawa 1988, s. 150. 
przypadku ustalenia porozumienia społecznego zostaną zrealizowane w trybie właściwym dla stanowienia rozporządzenia bądź dyrektywy ${ }^{7}$. Ważne przy tym jest, że ani Komisja, ani Rada nie są władne zmienić ustaleń dokonanych przez partnerów społecznych - organy te są zobowiązane albo w całości doprowadzić w drodze procesu legislacyjnego do wykonania porozumień normatywnych zawartych przez partnerów społecznych, albo powstrzymać się od wdrożenia tych ustaleń8.

Inną formą udziału partnerów społecznych w tworzeniu prawa socjalnego jest przewidziana przez art. 153 TFUE możliwość wprowadzania wspólnotowych dyrektyw w życie przez układy zbiorowe pracy obowiązujące w danym kraju członkowskim. Mianowicie, państwo członkowskie decydując, w jaki sposób dyrektywa ma być implementowana może, na wspólną prośbę przedstawicieli pracodawców i przedstawicieli pracowników, powierzyć im wprowadzenie w życie dyrektywy dotyczącej spraw socjalnych (choć nie zwalnia to władz danego kraju od odpowiedzialności za prawidłową implementację prawa wspólnotowego). Implementacja na tej drodze jest jednak możliwa tam, gdzie układy zbiorowe pracy są specyficznym, prawnie wiążącym źródłem prawa pracy i nie zezwalają na odstępstwa na niekorzyść pracowników, w indywidualnych umowach o pracę, od standardów określonych w takich porozumieniach normatywnych. W warunkach polskich nie jest jednak możliwa taka implementacja dyrektyw, gdyż prawo polskie nie dopuszcza zasadniczo objęcia regulacjami układowymi pracowników zatrudnionych w zakładach pracy, w których nie działają organizacje związkowe9 .

Oceniając znaczenie opisanych wyżej rozwiązań należy podnieść, że dla partnerów społecznych ważne jest, że przedstawiony tryb stanowienia

7 Czego przykładem są: dyrektywa 99/70//WE z dnia 28 czerwca 1999 r. dotycząca Porozumienia ramowego w sprawie pracy na czas określony, zawartego przez Europejską Unię Konfederacji Przemysłowych i Pracodawców (UNICE), Europejskie Centrum Przedsiębiorstw Publicznych (CEEP) oraz Europejską Konfederację Związków Zawodowych (ETUC) (DzUrz WE L 175 z 10.07.1999); dyrektywa 2010/18/UE z dnia 8 marca 2010 r. w sprawie wdrożenia zmienionego porozumienia ramowego dotyczącego urlopu rodzicielskiego zawartego przez BUSINESSEUROPE, UEAPME, CEEP i ETUC oraz uchylająca dyrektywę 96/34/WE (DzUrz UE L 68 z 18.03.2010, s. 13).

8 A.M. Świątkowski, Europejskie prawo socjalne..., s. 164. Por. też: M. Gładoch, Dialog społeczny w zbiorowym prawie pracy, Torun 2014, s. 250-251.

9 Por.: K. Walczak, w: Zarys systemu prawa pracy, t. I, Część ogólna prawa pracy, red. K.W. Baran, Warszawa 2010, s. 356; idem, w: System prawa pracy, t. V, Zbiorowe prawo pracy, red. K.W. Baran, Warszawa 2014, s. 972. Stąd też roli takiego narzędzia nie mogą odgrywać nawet układy zbiorowe pracy zawierane w trybie określonym przez ustawę o Trójstronnej Komisji, gdzie strona pracowników i strona pracodawców Komisji mogą zawierać ponadzakładowe układy zbiorowe pracy obejmujące ogół lub grupę pracodawców zrzeszonych $\mathrm{w}$ reprezentowanych w Komisji organizacjach pracodawców oraz pracowników zatrudnionych przez tych pracodawców. Por. też: M. Gładoch, Dialog społeczny..., s. 251. 
prawa zapewnia im wpływ na kształtowanie społecznych stosunków pracy w sposób, który uznają za najbardziej korzystny dla interesów reprezentowanych podmiotów. Zyskują w ten sposób gwarancję, że sprawy te nie będą przedmiotem regulacji samodzielnych przez instytucje wspólnoto$w^{10}$. Okoliczności wskazują też na to, że europejski dialog społeczny będzie kontynuowany. Są ku temu warunki, gdyż oczekuje tego Unia Europejska, domagają się go związki zawodowe, organizacje zaś pracodawców chcą zawierać takie umowy dla zachowania własnej wiarygodności i traktują je jako sposób unikania dyrektyw, na których treść nie miałyby żadnego wpływu ${ }^{11}$.

\section{Polski model tworzenia prawa ustawowego w świetle rozwiązań stosowanych przez MOP oraz UE i wnioski dla Polski}

Czy przedstawiony powyżej tryb tworzenia prawa pracy (prawa socjalnego) w Polsce jest jedynym możliwym rozwiązaniem? Pytanie to pojawia się z tego przede wszystkim powodu, że z takiego sposobu tworzenia tego prawa nie są zadowoleni adresaci jego norm. Modelowi owemu zarzucić można przede wszystkim zbytnie upolitycznienie treści prawa, a przez to także życia gospodarczego. Zarówno związki zawodowe, jak i pracodawcy podnosza, że kolejne nowelizacje prawa pracy realizują interes albo jednej, albo drugiej strony - zależnie od tego, z którą z nich sympatyzuje rządząca opcja polityczna lub czyj lobbing okaże się skuteczniejszy.

Pytając o sposób zmiany tej sytuacji zastanowić się trzeba, czy w Polsce właściwie uformowana została rola partnerów społecznych w procesie tworzenia prawa pracy, czy ich głos w tym procesie nie powinien przybrać charakteru bardziej stanowczego. Udział partnerów społecznych w tworzeniu prawa pracy jest elementem dialogu społecznego, umocowanego przecież w Konstytucji (art. 20), gdzie stanowić ma on podstawę ustroju gospodarczego państwa - obok zasad wolności gospodarczej, własności prywatnej i solidarności ${ }^{12}$. Rola państwa w tych ramach ograniczać się powinna do zagwarantowania minimum porządku społecznego, ze wzglę$\mathrm{du}$ na interes publiczny ${ }^{13}$. Tymczasem dialog społeczny $\mathrm{w}$ tym procesie odgrywa rolę marginalną.

10 A.M. Świątkowski, Europejskie prawo socjalne..., s. 168.

${ }^{11}$ R. Blanpain, Dialog społeczny. Współzależność gospodarcza i prawo pracy, [w:] Referaty na VI Europejski Kongres Prawa Pracy i Zabezpieczenia Społecznego, Warszawa 1999, s. 87.

12 Zdarzenia ostatnich lat pokazuja, że ustrój gospodarczy przyjął jako podstawy wolność gospodarczą i własność prywatną; całkowicie pomijając dialog społeczny i zasadę solidarności.

${ }^{13}$ M. Seweryński, Dialog społeczny. Współzależność gospodarki i prawa pracy, [w:] Referaty na VI Europejski Kongres Prawa Pracy..., s. 16. 
Dotychczasowe spojrzenie na rolę państwa w procesie tworzenia prawa pracy daje mu pozycję dominująca, ograniczającą $w$ tej sferze inicjatywy partnerów społecznych. Czy jednak doświadczenia i praktyka MOP oraz UE nie może być wzorem dla polskiego prawodawcy i podstawą do rozciagnięcia dialogu społecznego na tworzenie ustawowego prawa pracy. Pytanie to jest uzasadnione także tym, że w naszej praktyce legislacyjnej można wskazać sytuacje, w których głos partnerów społecznych miał znaczący wpływ na kształt regulacji prawa pracy. Przykładem jest Pakt o Przedsiębiorstwie Państwowym w trakcie przekształcenia z roku 1993, w którym uzgodniono zasady prywatyzacji tych przedsiębiorstw. Rezultatem tego porozumienia była regulacja prywatyzacji przedsiębiorstw państwowych, nowelizacje Kodeksu pracy dokonane w latach 1994-1996 czy unormowanie zasad działania funduszu gwarantowanych świadczeń pracowniczych. W ostatnim czasie przykładem tego rodzaju mogą być wynegocjowane $\mathrm{w}$ ramach Trójstronnej Komisji rozwiązania prawne dotyczące pracy tymczasowej, telepracy bądź regulacje antykryzysowe ${ }^{14}$.

Nie jest więc pozbawiona racji myśl o wzmocnieniu pozycji partnerów społecznych w tworzeniu prawa pracy w Polsce. Działalność gospodarcza jest polem, na którym spotykają się interesy przedsiębiorców i osób zatrudnionych; ponieważ w pewnym zakresie są one ze sobą sprzeczne, pojawia się dążenie do ich uzgodnienia. Drogą do osiągnięcia tego celu jest dialog - ale przede wszystkim dialog bezpośredni pomiędzy zainteresowanymi ${ }^{15}$.

Dla wzmocnienia pozycji partnerów społecznych w procesie tworzenia prawa przyjąć można różne rozwiązania. W szczególności rozważyć można wprowadzenie określonej formy akceptacji przez partnerów społecznych nowych regulacji prawnych z zakresu prawa pracy (prawa socjalnego) - jak już wcześniej zaznaczyłem obecne formy opiniowania nie gwarantuja, że nawet pozytywnie ocenione projekty nie zostaną zmienione $\mathrm{w}$ trakcie późniejszego procesu legislacyjnego. Innym sposobem może być dopuszczenie tworzenia przez partnerów społecznych na drodze uzgodnień pomiędzy nimi projektów aktów prawnych. Takie projekty rząd następnie mógłby zgłaszać w ramach własnego prawa do inicjatywy ustawodawczej, z zastrzeżeniem jednak, że bez zgody jego autorów projekt nie mógłby być modyfikowany na żadnym etapie prac parlamentarnych. Gwarancja ochrony interesu publicznego realizowana byłaby zarówno na etapie podjęcia przez Radę Ministrów decyzji o przyjęciu (albo odrzuceniu) projektu przed zgłoszeniem go jako inicjatywy

${ }^{14}$ Por. Z. Hajn, Zbiorowe prawo pracy. Zarys systemu, Warszawa 2013, s. 123.

15 Por. M. Seweryński, Dialog społeczny. Współzależność gospodarki i prawa pracy..., s. 17. 
ustawodawczej, jak i następnie $\mathrm{w}$ trakcie realizacji procesu legislacyjnego w parlamencie, gdzie projekt mógłby zostać odrzucony. Wskazane zabezpieczenia wydają się wystarczające, zważywszy na konieczność zapewnienia ochrony interesów wszystkim uczestnikom rynku czy wynikającą z zasady sprawiedliwości społecznej potrzebę, by korzyści uzyskane przez pracowników ${ }^{16}$ zostały rozciągnięte na wszystkich zatrudnionych ${ }^{17}$.

Korzyści z przyjęcia zaproponowanych rozwiązań mogą być wielorakie. Przede wszystkim będzie to akceptacja takiego prawa przez partnerów społecznych, poprzez to, że w ich propozycji zaspokojone zostaną ich własne interesy jako głównych adwersarzy. Z kolei pozycja partnerów społecznych jako podmiotów bezpośrednio narażonych na oddziaływanie procesów rynkowych, odpowiednio wcześnie pozwoli reagować na potrzeby społeczne i zjawiska naruszające pokój społeczny ${ }^{18}$. Nadto w ten sposób ograniczy się także zjawisko cząstkowych i epizodycznych nowelizacji prawa pracy podejmowanych z inicjatywy różnych podmiotów, najczęściej pod wpływem doraźnej koniunktury politycznej; ograniczona zostanie także praktyka preferowania uprawnień jednej ze stron dialogu społecznego czy też dawanie takich uprawnień przez jedną władzę i odbieranie ich po zmianie układu parlamentarnego ${ }^{19}$.

Niewątpliwie zaproponowany model ma też wady, jak choćby taka, że niemożność osiągnięcia zgody co do określonych rozwiązań prawnych może spowodować niekiedy brak legislacyjnej reakcji na nowe zjawiska gospodarcze lub społeczne - ale wówczas będzie można stosować zwykłe procedury legislacyjne. Trzeba też mieć świadomość, że w Polsce dotychczasowe praktyki w zakresie funkcjonowania przedstawicielstw pracowników i pracodawców doprowadziły do daleko idącego ich upolitycznienia - rezultatem tego jest też brak rozpowszechnionej regulacji układowej, zwłaszcza na poziomie branżowym, oraz dążenie przez centralne struktury związków zawodowych i organizacji pracodawców do wypełnienia tej luki poprzez oddziaływanie na prawo ustawowe $\mathrm{z}$ wykorzystaniem przedstawionych wcześniej uprawnień konsultacyjnych, jak i poprzez lobbing polityczny. W mojej ocenie ta ostatnia okoliczność przemawia jedynie za tym, by zapewnić partnerom społecznym odpowiedni czas na przygotowanie się do grania nowych ról.

${ }^{16}$ Należy bowiem mieć na uwadze, że związki zawodowe obecnie reprezentują przede wszystkim pracowników.

17 Por. M. Seweryński, Dialog społeczny. Współzależność gospodarki i prawa pracy..., s. 17.

18 Por. M. Seweryński, Kryzys gospodarczy i prawo pracy, [w:] Prawo pracy. Refleksje i poszukiwania. Księga Jubileuszowa Profesora Jerzego Wratnego, red. G. Uścińska, Warszawa 2013, s. 30 .

19 T. Zieliński, Reforma prawa pracy..., s. 20-21. 


\section{Bibliografia}

Blanpain R., Dialog społeczny. Współzależność gospodarcza i prawo pracy, [w:] Referaty na VI Europejski Kongres Prawa Pracy i Zabezpieczenia Społecznego, Warszawa 1999.

Gładoch M., Dialog społeczny w zbiorowym prawie pracy, Toruń 2014.

Hajn Z., Zbiorowe prawo pracy. Zarys systemu, Warszawa 2013.

Mitrus L., Tendencje rozwojowe wspólnotowego prawa pracy, „Państwo i Prawo” 2003, nr 7.

Seweryński M., Dialog społeczny. Współzależność gospodarki i prawa pracy, [w:] Referaty na VI Europejski Kongres Prawa Pracy i Zabezpieczenia Społecznego, Warszawa 1999.

Seweryński M., Kryzys gospodarczy i prawo pracy, [w:] Prawo pracy. Refleksje i poszukiwania. Księga Jubileuszowa Profesora Jerzego Wratnego, red. G. Uścińska, Warszawa 2013.

Świątkowski A.M., Europejskie prawo socjalne, t. I, Specyfika, stanowienie i stosowanie europejskiego prawa socjalnego, Warszawa 1988.

Walczak K. w: System prawa pracy, t. V, Zbiorowe prawo pracy, red. K.W. Baran, Warszawa 2014.

Walczak K. w: Zarys systemu prawa pracy, t. I, Czesść ogólna prawa pracy, red. K.W. Baran, Warszawa 2010.

Włodarczyk M. w: System prawa pracy, t. V, Zbiorowe prawo pracy, red. K.W. Baran, Warszawa 2014.

Wratny J., Dylematy polityki prawa w zakresie wynagrodzenia za pracę, [w:] Prawo pracy a wyzwania XXI wieku. Księga jubileuszowa Profesora Tadeusza Zielińskiego, red. M. Matey-Tyrowicz, L. Nawacki, B. Wagner, Warszawa 2002.

Zieliński T., Reforma prawa pracy (Problemy legislacyjne), „Państwo i Prawo” 2002, nr 5.

\section{Participation of Social Partners in the Process of Establishment of Labour Law Legislation}

\section{Summary}

The subject of the following analysis is the point to which usually no attention is paid during the work of the statutory changes in labour law, and which is undoubtedly important for the effective application of this law and its development. It is about how to create draft legislative acts in the field of labour law (social law) in Poland. The participation of social partners in this process, namely the representatives of workers and employers, is an unquestionable principle of the law-making process in the field of labour law (social law).

This text contains proposals to strengthen the role of social partners in this process. To achieve this, the introduction of a particular form of acceptance of new regulations in the field of labour law (social law) by the social partners may be considered. Another way might be the opportunity to negotiate draft legal acts by the social partners. The government could then propose such project using the right of legislative initiative. However, the proposal could not be modified at any stage of parliamentary work without the consent of the social partners.

Public interest in these cases will be protected by the government when deciding on the adoption (or rejection) of the draft before submitting it as a legislative initiative. The protection of public interest will also continue during the implementation of the legislative process in the Parliament, where the project may be rejected. 